\title{
Pemanfaatan Teknologi Informasi dan Manajemen Perubahan Organisasi dalam Mendukung Bisnis Berkelanjutan Pasca Covid-19 pada UMKM di Kota Bengkulu (Utilization of Information Technology and Organizational Change Management to support Post-Covid 19 Sustainable Business for MSMEs in Bengkulu City)
}

Hafiza Tri Murti ${ }^{*}$, Veny Puspita $^{2}$, Puspa Ratih ${ }^{3}$

Universitas Prof. Dr. Hazairin, S.H. Bengkulu

hafizalizahari05@gmail.com $^{1 *}$, venypuspita2288@ gmail.com ${ }^{2}$, pusparatih15@gmail.com $^{3}$

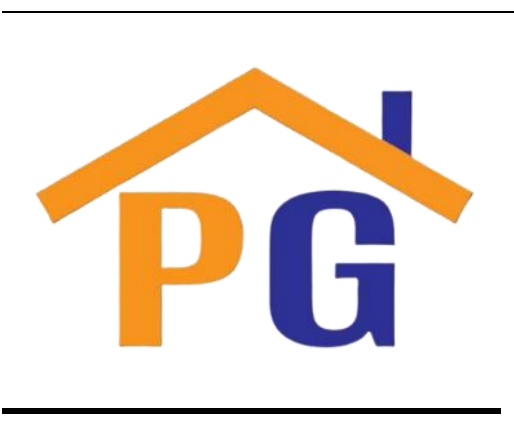

Riwayat Artikel

Diterima pada 30 Mei 2021

Direvisi pada 24 Juni 2021

Disetujui pada 1 Juli 2021

\begin{abstract}
The purpose of this study is to examine how information technology and organizational change management can be used to support sustainable business in Bengkulu City MSMEs following Covid-19. To survive the COVID-19 pandemic, the role of information technology and organizational change management is critical, as information technology serves as a manager of the information available at the time. Change management provides a structured approach for assisting individuals within an organization in transitioning from their current state to their desired state. Organizational change management is concerned with identifying groups and individuals who must change. Not only that, organizational change management entails the development of customized plans for successfully implementing the change. The primary objective of change management is to prepare for a smooth, successful transition.
\end{abstract}

Keywords: Information Technology, Organizational Change Management, Sustainable Business

How to cite: Murti, H. T., Puspita, V., \& Ratih, P. (2021). Pemanfaatan Teknologi Informasi dan Manajemen Perubahan Organisasi dalam Mendukung Bisnis Berkelanjutan Pasca Covid-19 pada UMKM di Kota Bengkulu. Jurnal Bisnis dan Pemasaran Digital, 1(1), 33-41.

\section{Pendahuluan}

Di zaman yang canggih seperti saat ini, kita tak asing lagi mendengar kata-kata teknologi. Semakin berkembangnya teknologi maka juga semakin banyak bidang yang perlu untuk dikembangkan. Salah satunya adalah teknologi informasi. Jack \& Akujobi (2017) menyebutkan bahwa teknologi seperti internet yang digunakan dapat membentuk budaya dan masyarakat bahkan internet telah menjadi bagian dari struktur sosial masyarakat. Apalagi hasil survei Kominfo pada tahun 2017 menunjukkan bahwa lebih Ini merupakan bidang yang berkaitan erat dengan perkembangan teknologi.

Tanpa adanya teknologi informasi mungkin perkembangan yang terjadi tidak akan semaju ini. Pengertian teknologi informasi secara umum yaitu merupakan sistem mengembangkan, teknologi secara berbasis perangkat lunak yang berguna sebagai aplikasi. TI bukan hanya teknologi biasa, melainkan merupakan perangkat penting yang seharusnya dimiliki dalam bisnis sebagai sarana untuk berkoordinasi dan pengarsipan dokumen-dokumen penting. hanya teknologi biasa, melainkan merupakan perangkat penting yang seharusnya dimiliki dalam bisnis sebagai sarana untuk berkoordinasi dan pengarsipan dokumen-dokumen penting. 
Abdul Kadir (2014), mengemukakan bahwa teknologi informasi secara garis besar mempunyai peran sebagai berikut:

1. Peran manusia digantikan oleh teknologi. Dalam hal ini, teknologi informasi melakukan otomasi terhadap suatu tugas atau proses.

2. Peran manusia diperkuat oleh teknologi informasi, seperti menyajikan informasi terhadap suatu tugas atau proses.

3. Dalam restrukturisasi terhadap manusia, teknologi informasi sangat berperan. Karena teknologi berperan dalam melakukan perubahan perubahan terhadap sekumpulan tugas atau proses.

Penerapan teknologi informasi berguna sebagai sumber informasi sangat berperan penting untuk melakukan suatu tugas di suatu sistem informasi, dan memiliki respon yang sangat akibat dari tekanan persaingan bisnis. akibat dari tekanan persaingan bisnis. Pemerintah Republik Indonesia sejatinya telah memberikan pembekalan melalui Undang-undang Nomor. 19 tahun 2016 tentang Informasi dan Transaksi Elektronik maupun Peraturan Presiden Nomor. 74 tahun 2017 tentang Peta Jalan Sistem Perdagangan Gambar 3.8. Skema Komunikasi Jaringan Sensor 30 Nasional Berbasis Elektronik. Kedua payung hukum tersebut diluncurkan untuk memberikan penegasan tentang arti penting percepatan perwujudan potensi ekonomi.

Di era pandemi ini banyak sekali UMKM yang hampir tidak beroperasi lagi dikarenakan adanya peraturan pemerintah yang mengharuskan masyarakatnya untuk standby di rumah agar tercegahnya penyebaran virus ini. UMKM sangat berperan penting bagi perekonomian masyarakat, karena membuat lapangan pekerjaan . suatu bisnis mendukung masyarakat yang memiliki penghasilan yang tidak terlalu tinggi untuk membuat kegiatan usaha bisnis yang sangat produktif. Bukan hanya usaha kecil saja semua usaha memiliki peran sangat penting khususnya di Indonesia pada era milenial ini tidak bisa dipungkiri lagi, secara perlahan lahan semua beralih ke arah digital, sehingga pada saat ini teknologi informasi tidak dapat dipungkiri karena semua orang sudah memiliki teknologi masing-masing, dari teknologi tersebut bisa di lakukan seperti membeli kebutuhan rumah tangga dan lainnya , menjual barang yang tidak dibutuhkan lagi dan masih banyak lagi untuk berbisnis. Selain teknologi informasi, untuk mendukung bisnis berkelanjutan digunakan peran manajemen perubahan organisasi. Tidak bisa dipungkiri lagi, secara perlahan lahan semua beralih ke arah digital, hingga berbisnis. Selain teknologi informasi, untuk mendukung bisnis berkelanjutan digunakan peran manajemen perubahan organisasi.

Manajemen perubahan adalah bentuk usaha yang dilakukan guna mengelola seluruh akibat yang dihasilkan karena adanya perubahan dalam suatu perusahaan. Manajemen perubahan adalah alat, proses, dan juga teknik untuk mengelola manusia pada sisi proses perubahan dalam menggapai hasil yang dibutuhkan dan demi mewujudkan perubahan secara efektif pada suatu tim, individu, dan sistem yang lebih luas. Perencanaan yang tepat untuk mempersiapkan, melengkapi, dan mendukung individu diorganisasi agar berhasil mengambil perubahan untuk menekankan keberhasilan organisasi adalah bagian dari definisi manajemen perubahan. Perubahan dapat terjadi berasal dari dalam maupun luar organisasi tersebut. Sebagian orang banyak yang tidak menyukai adanya perubahan, tetapi meskipun begitu perubahan tidak bisa dihindari dan harus di hadapi. Agar mendapatkan perubahan yang baik ke depannya maka diperlukan manajemen perubahan, karena manajemen perubahan memberikan pendekatan untuk menekankan pengambilan dan penggunaan sistem baru di sebuah organisasi, sehingga membutuhkan hasil yang inginkan.

Di kehidupan yang terus berubah, seperti pasar yang mengglobal dan terciptanya teknologi baru, maka sangatlah hakiki dunia bisnis juga wajib berubah agar terus berkembang dengan baik. Sebuah perusahaan yang bisa beradaptasi baik dan benar secara dinamis dan inovatif terhadap setiap sanggahan baru adalah perusahaan yang sukses. Perubahan yang terjadi tidak datang begitu saja, pihak manajemen membutuhkan pendekatan yang tersusun guna perencanaan perubahan perilaku atau Sumber Daya Manusia. Manajemen perubahan menghadirkan pendekatan tersusun untuk mendukung individu yang ada diorganisasi dan berpindah ke status mereka dari yang sekarang ke yang akan datang. Pemahaman kelompok dan orang yang perlu berubah sebagai hasil dari proyek dan dengan cara seperti apa yang mereka gunakan untuk berubah adalah perlibatan dari manajemen perubahan organisasi. Manajemen 
perubahan organisasi juga mengaitkan pembuatan rencana yang disesuaikan untuk memastikan SDM yang terkena dampak menerima kepemimpinan dan pelatihan. Pelatihan yang mereka butuhkan agar berubah ke arah yang baik, dan menyiapkan peralihan yang baik agar menjadi titik fokus utama pada kegiatan dalam manajemen perubahan organisasi.

Yudhaningsih (2011) menyatakan perubahan organisasi berperan terhadap efektivitas kerja yang berarti bahwa setiap peningkatan perubahan organisasi satu satuan akan berpengaruh terhadap peningkatan efektivitas kerja. Menurut peneliti Rodriguezet,all 2016, tentang menganalisa perubahan organisasi tertentu yang terjadi setelah privatisasi, dimana lebih khusus peneliti menganalisis sari perspektif teori keagenan bagaimana perubahan pada tingkat tata kelola perusahaan (tipe kepemilikan, struktur dan dewan direksi) mempengaruhi strategi perusahaan dan apa implikasi masalah ini harus untuk desain mekanisme kompensasi. Isi penelitian :

1) Variable yang secara tradisional berhubungan dengan kebebasan taktik perubahan yang lebih besar dalam pemantauan tidak terikat setelah privatisasi.

2) Kepentingan kepemilikan baru perusahaan berdampak pada strategi perusahaan setelah privatisasi. Akhirnya desain sistem kompensasi sejalan dengan strategi perusahaan setelah privatisasi.

Sebagaimana daerah lainnya di Indonesia, UMKM Kota bengkulu juga telah berkembang pesat dan menunjukkan peran pentingnya dalam perekonomian masyarakat di daerah ini. Jumlah UMKM yang tersebar di Provinsi Bengkulu menurut Dinas Koperasi dan UKM mencapai sekitar 44 Ribu, artinya sangat banyak masyarakat pelaku usaha yang terpukul oleh pandemi Covid-19. -Kanwil. DJpb PROV Bengkulu, 08 Juli 2020. Mengingat pentingnya peran UMKM tersebut maka perlu dilakukan kajian lebih jauh mengenai UMKM di Kota bengkulu, khususnya yang terkait dengan pemanfaatan teknologi informasi dan manajemen perubahan organisasi. Hal ini ditujukan dalam daya saing UMKM di Kota bengkulu dapat meningkat menghadapi era persaingan di pasar global untuk bisnis yang berkelanjutan.

\section{Landasan Teori dan Perkembangan Hipotesis}

Kondisi yang terjadi di era modern ini teknologi cepat berkembang dengan sangat pesat. Bisnis baru dan inovasi baru di bidang teknologi selalu dilakukan setiap hari guna memajukan UMKM untuk pintar mengelola teknologi yang canggih dan bermanfaat bagi kebutuhan manusia. Setiap rencana suatu manajemen sangat bersangkutan dengan jasa suatu karyawan. Karena karyawan sangat berperan penting bagi perusahaan apabila tidak memiliki hubungan baik terhadap karyawan akan berakibat tidak lancarnya suatu pekerjaan dan memiliki pemikiran negatif bagi karyawan.

\section{Teknologi informasi}

Dalam suatu bisnis teknologi informasi (TI) berperan untuk sarana transaksi beberapa jenis bisnis online, yaitu dalam memberikan fasilitas media internet. web yang di sediakan sebagai tempat konsumen memilih barang-barang yang diinginkan, dan pada transaksi ini pun dibutuhkan teknologi lain untuk mendukung bisnis online tersebut, yaitu dibutuhkan teknologi komunikasi telepon (sebagai media komunikasi), bank ( media pembayaran konsumen dengan produsen), agen pengiriman seperti pos Indonesia. hal-hal tersebut merupakan teknologi yang berpengaruh dalam perkembangan bisnis online.

Kemudahan-kemudahan dan fasilitas yang tersedia akibat peranan dan pengaruh TI ini membuat bisnis online lebih banyak dimanfaatkan karena lebih efisien, menghemat waktu dan lebih cepat yang dirasakan baik oleh produsen dan konsumen. Sejalan dengan berkembangnya dunia Teknologi Informasi, peran TI tidak hanya berupa desain aplikasi, menggunakan web, database, instagram, dan facebook, pembangunan jaringan dan hal teknik lainnya. Teknologi informasi sudah menjadi bagian yang sangat penting terhadap perkembangan bisnis, bahkan dapat meningkatkan dapat membuat bisnis lebih menguntungkan. Sedangkan menurut Aminah, S. (2016), "Peranan teknologi informasi telah menjadi fasilitator utama bagi kegiatan-kegiatan bisnis, memberikan adil besar terhadap perubahanperubahan yang mendasar pada struktur, operasi, dan manajemen organisasi." 


\section{Kemudahan Teknologi Informasi}

Kemudahan teknologi informasi untuk manajemen organisasi guna mendukung bisnis berkelanjutan sangat penting untuk para peluang bisnis, berkelanjutan sangat penting untuk para peluang bisnis , kegunaan teknologi dan komunikasi sanggat berperan penting untuk melakukan kegiatan usaha .

Mengutip studi Chayapa \& Cheng Lu (Permadi, et al,2108) menyebutkan bahwa ada beberapa faktor yang mempengaruhi keputusan seseorang untuk berbelanja online shopping yakni:

1) Kenyamanan. Faktor ini penting mengingat sebagian besar masyarakat mulai berusaha menghindari keramaian hingga berdesak-desakan saat berbelanja dipusatpusat perbelanjaan. Dengan demikian pilihan untuk berbelanja di online shopping menjadi alternatif baru yang bisa membuat lebih efektif.

2) Kelengkapan informasi. hadirnya teknologi informasi membuat akses terhadap informasi begitu cepat dan mudah, hal itu di tambah dengan banyaknya platform yang telah menyediakan beragam informasi, fitur, rating dan review hingga memberikan ulasan tentang kualitas dan informasi sebuah produk.

3) Ketersediaan produk dan jasa. hanya dengan mengakses website, masyarakat dapat dengan cepat mengetahui ketersediaan barang tanpa harus berkunjung ke toko tersebut. hal ini juga dapat membantu calon pembeli yang berlokasi jauh dengan toko, dengan tidak perlu berkunjung namun tetap dapat membeli barang secara online.

4) Efisiensi biaya dan waktu beberapa website sering menawarkan kepada calon pembeli harga terbaik dengan membandingkan harga di beberapa toko sekaligus. Perbandingan harga ini menjadi berarti bagi calon pembeli. Apalagi model online shopping dapat dilakukan dimana saja dan kapan saja.

Rizki (2015), Teknologi informasi daya guna minat beli konsumen untuk keputusan membeli secara digital atau online terhadap survei konsumen ardi, hasil dari setiap penelitian bahwa setiap komunikasi memiliki kemudahan dan efektivitas sangat berpengaruh pada minat beli konsumen, Dari analisis tersebut bahwa sistem informasi digital sangat berpengaruh pada minat beli ardi dan adannya kualitas pada setiap barang yang dijual secara online sangat berpengaruh pada minat beli konsumen. Manajemen perubahan organisasi Perubahan dilingkungan bisnis, di era ekonomi berkelanjutan, teknologi membuat beberapa pebisnis mengalami situasi yang selalu berubah. Setiap perubahan akan membuat sistem atau proses strategi pebisnis. Maka pebisnis harus pintar membuat perubahan secara efektif dan efisien. Pemanfaatan teknologi bagi UMKM di masa pandemi dan untuk masa yang akan datang.

Rizki (2015), beberapa kemudahan dan kualitas barang terhadap minat beli konsumen melalui beberapa mesin digital dalam pembelian online, konsumen ardi mencari beberapa barang di online, dalam hal ini betapa mudahnya untuk membeli suatu produk secara online dan dalam waktu yang signifikan, untuk mempengaruhi konsumen tersebut yaitu dengan informasi iklan yang di tayangkan melalui media sosial dari sana pengaruh minat beli konsumen dan adanya kualitas informasi yang akurat memiliki pengaruh minat beli konsumen.

\section{Manajemen perubahan organisasi}

Perubahan dilingkungan bisnis, di ekonomi Setiap bisnis memiliki modifikasi di setiap perekonomian secara global atau mengikuti era, kemajuan teknologi sangat berpengaruh terhadap peluang bisnis yang cukup berubah sangat pesat. Perubahan saat ini sangat berpengaruh pada sistem, strategi pemasaran bisnis, proses penjualan. Perubahan tersebut sangat berpengaruh penting agar bisnis terus berkembang kompetitif terhadap pesaing bisnis.

Menurut Courtney 2016. 6 strategi agar manajemen perubahan organisasi mencapai target secara tepat waktu:

1. Mendefinisikan sangat jelas setiap perubahan dengan tujuan suatu bisnis.

Sangat jelas banyak beberapa pebisnis mengabaikan langkah penting. Membuat perubahan yang dilakukan bertujuan kritis terhadap tujuan suatu bisnis dan kinerja kerja, dengan berpikir atau menerapkan perubahan membuat bisnis ke arah yang strategis dan efektif. Pada langkah 
ini dapat menumbuhkan rasa percaya terhadap beberapa orang yang akan berinvestasi ke bisnis kita, pastikan setiap dampak dan risiko, setelah mengetahui pebisnis dan manajemen yang bisa menentukan suatu perubahan di setiap bisnis . Perlu beberapa survei efek pada setiap bisnis dan bagaimana bisnis tersebut berkembang pesat melalui struktur bisnis ke individu.

\section{Membuat struktur anggota}

Mempersiapkan struktur anggota berguna membantu para karyawan melalui perubahan secara emosional. Selain itu keterampilan juga berperan penting untuk mendapatkan hasil pencapaian bisnis yang diinginkan. Dari perubahan tersebut mengakibatkan peniruan restrukur, sebagai pebisnis memberikan dukungan secara motivasi melalui konseling untuk mengatasi suatu permasalahan. Memberikan jadwal sesi tanya jawab untuk mengatasi setiap masalah di setiap pekerjaan pada karyawan.

\section{Mengembangkan strategi informasi}

Dalam perusahaan karyawan sangat terlibat dalam setiap pengembangan informasi dan komunikasi pada saat perusahaan tersebut mengalami perubahan. Strategi informasi meliputi beberapa perubahan komunikasi secara bertahap, dan memiliki saluran media komunikasi yang selalu digunakan.

\section{Melaksanakan pelatihan bagi karyawan}

Agar karyawan memiliki kemampuan yang terstruktur, karyawan berhak mendapatkan proses pembelajaran untuk mendukung kinerja karyawan para karyawan agar karyawan tersebut dapat bekerja dengan baik dalam hal pembelajaran tersebut yaitu proses pelatihan secara langsung dan tidak langsung, mendapatkan pembinaan dan modul pembelajaran.

\section{Melaksanakan struktur motivasi kerja}

Melaksanakan struktur motivasi kerja sangat penting agar karyawan dapat mengatasi suatu problem yang ada di perusahaan, selain itu perilaku dan keterampilan karyawan sangat penting untuk hasil bisnis yang diinginkan. Pebisnis harus memiliki hubungan yang baik agar karyawan dapat membuat perusahaan lebih maksimal lagi dalam hal ini perlu melakukan layanan konseling untuk mengatasi setiap masalah yang ada di perusahaan mengajukan pertanyaan dalam sesi tersebut agar semua masalah yang ada di setiap karyawan dapat diketahui oleh pebisnis.

\section{Menguji beberapa proses alternatif}

Beberapa proses manajemen alternatif, dalam struktur beberapa hal yang perlu di perhatikan dampaknya dari bisnis dan perubahan peluang bisnis berkelanjutan untuk membuat suatu usaha tersebut semakin berkembang dan berbagai keahlian, mampu mengevaluasi suatu perancangan setiap manajemen untuk menjadikan bisnis berkreatif dan memberikan pelajaran yang bermanfaat.

\section{Manajemen perubahan bagi UMKM Untuk mengatasi perubahannya.}

Pada saat ini dan ke depannya, pebisnis mampu mengubah manset penjual yang akan membuat penjualan menjadi lebih banyak di minati oleh konsumen. Dengan cara mengubah bentuk penjualan dengan digital marketing yang lebih menarik dan mampu membuat calon konsumen tertarik akan suatu produk yang ditawarkan UMKM agar unit usaha yang dibuka di ranah digital bukan hanya sekadar sebagai pelengkap, akan tetapi bisa diharapkan bertahan lama. Oleh sebab itu diperlukan strategi pengembangan secara digital terhadap UKM dalam penyediaan infrastruktur teknologi informasi, proses produksi, dan perluasan pasar baik dalam jangka pendek, jangka menengah, dan jangka panjang agar para usaha kecil menengah memiliki daya saing dan dapat meningkatkan kinerjanya (Slamet,et al, 2016). 
Berikut, hal-hal yang menjadi alasan bagi kita memerlukan manajemen perubahan:

1. Berkembang di dunia yang selalu berubah.

2. Tutup kesenjangan antara persyaratan dan hasil.

3. Mengurangi risiko.

4. karyawan dengan benar.

\section{Metode Penelitian}

\section{Jenis Penelitian}

Beberapa jenis penelitian yang dapat digunakan sebagai berikut jenis kualitatif Korelasional. Korelasional adalah usaha penelitian yang dilakukan dengan cara pengumpulan data untuk dapat memutuskan memilih dan bisa menentukan antara variabel satu dengan dua ataupun juga bisa lebih dari dua variabel.

\section{Sumber Data}

Data Primer

Sumber data primer pada penelitian ini didapat melalui kegiatan survei, observasi dan media lain yang digunakan untuk memperoleh data lapangan. Dan membutuhkan sumber daya, seperti waktu tenaga.

\section{Data Sekunder}

Data sekunder beberapa peneliti menggunakan suatu penelitian dalam melalui media dan penelitian tersebut berperan penting terhadap beberapa pihak dikarenakan tidak bisa digunakan secara langsung

\section{Metode Perbandingan Data}

Metode pengumpulan data yang digunakan oleh peneliti yaitu menggunakan media perantara dan observasi. Media terdiri dari berbagai bahas yang memiliki banyak arti dari medium yang artinya perantara atau pengantar pesan (Ali mudlofir dan Eni Fatimatur: 2016 dalam Andi Wardana, 2018:13).

\section{Teknik Analisis Data}

Analisis yang digunakan adalah analisis data kualitatif. Bogdan (dalam Sugiyanto, 2018, hlm. 334) menyatakan bahwa analisis data dalam penelitian kualitatif adalah proses mencari dan menyusun secara sistematis data yang diperoleh dari hasil wawancara, catatan lapangan, dan bahan-bahan lain sehingga lebih mudah dipahami, dan temuannya dapat diinformasikan kepada orang lain.

\section{Keabsahan Data}

Menggunakan uji validitas dan uji reliabilitas, yang digunakan untuk menguji daftar pertanyaan untuk melihat pertanyaan dalam kuesioner yang diisi responden sudah layak atau belum yang digunakan untuk mengambil data.

Dengan demikian penelitian ini menggunakan Korelasional adalah usaha penelitian yang dilakukan dengan cara pengumpulan data untuk dapat memutuskan memilih dan bisa menentukan antara variabel satu dengan dua ataupun juga bisa lebih dari dua variabel.

\section{Pembahasan}

\section{Kebijakan melalui Peran Teknologi Informasi}

Teknologi Informasi diterapkan guna untuk pengelolaan informasi yang pada saat ini menjadi salah satu bagian penting dalam menjalankan bisnis seperti UMKM dalam era pandemi Covid-19 agar menjadi bisnis berkelanjutan. Untuk mendorong tingkat kesejahteraan UMKM di Kota Bengkulu, perlu melalukan berbagai kebijakan melalui peran teknologi informasi, Guna untuk memajukan Bisnis yang berkelanjutan. Peran-peran tersebut adalah:

\section{Mempermudah Komunikasi}

Beberapa perusahaan, email berperan sangat penting untuk melakukan komunikasi setiap karyawan, distributor dan konsumen. Email adalah alat komunikasi pertama pada jaringan sosial media, dalam 
penggunaannya sangat cepat dan efektif jauh lebih baik apabila menggunakan faksimile untuk melakukan komunikasi internet. Setiap tahunnya, alat komunikasi semakin berkembang pesat, ada pun beberapa karyawan melakukan komunikasi menggunakan chatting di fitur aplikasi lainnya yang sangat mudah. Untuk melakukan mitting secara online juga bisa menggunakan aplikasi zoom metting, goggle meet, Microsoft Teams dan banyak lagi aplikasi pendukung lainnya.

\section{Memberikan Ilmu Pengetahuan dan Sumber Informasi Bisnis}

Dengan menggunakan internet, kalian cukup mudah untuk melakukan browsing dengan menggunakan Google atau Mozila, semua informasi yang kalian cari sudah tersedia di sana. Internet bisa membuat Anda mendapatkan ilmu pengetahuan tentang cara bagaimana mengembangkan suatu bisnis dan lain sebagainya, semakin banyak ilmu yang kalian cari di internet tersebut semakin banyak juga pengetahuan tentang bisnis yang akan dikembangkan. Di sana kita bisa melihat informasi tentang pesaing bisnis yang sama akan hal bisnis yang kita buat.

\section{Sistem informasi Manajemen Data}

Di era modern sekarang arsip penting berupa dokumen-dokumen perusahaan sudah sangat mudah untuk di simpan dan sangat mudah untuk di cari apabila perusahaan tersebut membutuhkan dokumen tersebut, karena jaman sekarang sudah canggih tidak lagi menyimpan dokumen menggunakan lemari arsip. Namun menggunakan penyimpanan dokumen digital. Setiap perusahaan memiliki penyimpanan jumlah data historis, sehingga setiap karyawan dapat mengakses langsung menggunakan akun atau halaman web di sistem informasi manajemen perusahaan sehingga dapat digunakan secara efektif dan efisien. Sistem informasi perusahaan dapat melacak data perusahaan, biaya dan penjual setiap perusahaan. Dari sistem informasi manajemen tersebut manajer dapat memantau penjualan setiap harinya apabila penjualan tersebut mengalami penurunan penjualan dari perkiraan dan dapat meningkatkan produktivitas karyawan atau mengurangi beberapa produk yang tidak digunakan.

\section{Interaksi Perusahaan kepada Pelanggan}

Setiap perusahaan menggunakan teknologi informasi membagun pendekatan untuk mengelola hubungan dengan pelanggan. Interaksi perusahaan kepada pelanggan Secara khusus mereka berusaha memberikan layanan yang sifatnya personal sehingga dapat memberikan pelayana yang baik pada pelanggannya, apabila pelanggan mengalami masalah pada suatu produk, pelanggan dapat langsung menghubungi call center mengenai informasi pengiriman barang yang pelanggan pesan. Dengan adanya interaksi perusahaan kepada pelanggan ,karyawan dapat menginformasikan keberadaan barang pesanan pelanggan. Dengan adanya pelayanan yang sangat cepat dapat memberikan keuntungan bagi perusahaan karna pelanggan mendapatkan pelayanan yang memuaskan.

\section{Pelayanan Bisnis Selama 24 Jam}

Perkembangan teknologi informasi sangat berperan penting pada pelaku bisnis untuk memberikan pelayanan jual beli online selama 24 jam, beda halnya dengan toko offline atau pembelian secara langsung datang ke toko pelayanannya sangat terbatas karena memiliki waktu tidak lebih dari 24 jam . berkembangnya ilmu pengetahuan dan teknologi sekarang membuat pelaku usaha memudahkan pelayanan setiap bisnis, setiap bisnis diperlukan ilmu pengetahuan, kreativitas, agar dapat sukses bersaing di dunia bisnis.

\section{Peran Manajemen Perubahan Organisasi}

Selain teknologi informasi peran manajemen perubahan organisasi juga sangat penting guna menjalankan UMKM di era pandemi dan menjadikannya bisnis berkelanjutan. Ada beberapa hal yang perlu di perhatikan untuk membuat perubahan baru:

\section{Bagaimana dapat Bersaing di Era yang Selalu Membuat Produk Baru}

Beberapa komunitas mendapatkan perubahan yang sangat signifikan, tergantung bagaimana kita memberikan hasil atau perubahan setiap usaha untuk mencapai usaha yang strategis dan berkembang dalam sebuah bisnis yang sangat cepat berubah pada era modern ini. Membuat perubahan memungkinkan komunitas untuk memberikan ide dan hasil secara efektif dan efisien dan dapat membuat komunitas yang banyak dalam waktu tertentu. 
Membuat Perbedaan antara Persyaratan dan Hasil

Perbedaan organisasi dapat memberikan syarat dan hasil yang sangat signifikan memberikan hasil yang sangat diperlukan tanpa yang diharapkan organisasi fokus pada menutup kemungkinan orang-orang yang dapat mengalami perubahan suatu hasil agar dapat membuat cara kerja suatu organisasi berjalan dengan lancar tanpa ada kendala.

\section{Mengurangi Risiko Kendala Suatu Produk}

Perubahan setiap seseorang dapat menimbulkan risiko yang sama. ketika suatu komplain atau suatu kendala di abaikan dalam dunia bisnis , akan mendapatkan risiko tidak dapatnya kepercayaan seseorang terhadap suatu produk tersebut sehingga menimbulkan biaya yang tak terduga, maka dari itu setiap manajemen perubahan harus bersikap disiplin dalam menghadapi suatu kendala agar dapat mengurangi kepercayaan suatu pelanggan dan nantinya menimbulkan ketidakpercayaan suatu seseorang terhadap produk yang mereka beli.

\section{Perlakukan Setiap Karyawan dengan Baik}

Setiap karyawan memiliki hak dan kewajiban setiap perusahaan, karena karyawan adalah aset perusahaan yang sangat berharga. Setiap karyawan akan mempunyai hak untuk mendapatkan jabatan yang seharusnya mereka dapat agar memiliki motivasi atau niat kerja yang akannya menguntungkan perusahaan. sama halnya dengan perlakuan jam kerja setiap karyawan harus sama karena kita harus menghargai mereka tanpa adanya mereka perusahaan tidak akan berjalan dengan lancar.

\section{Kesimpulan}

Teknologi informasi menjadi bagian penting dalam menjalankan bisnis seperti UMKM di era pandemi Covid-19. Teknologi informasi diterapkan untuk mengelola informasi yang saat ini digunakan oleh pelaku usaha UMKM. Peran tersebut adalah: Memfasilitasi komunikasi, memberikan informasi dan memantau penjualan. Setiap perusahaan yang menggunakan teknologi informasi membangun pendekatan untuk mengelola hubungan pelanggan. Manajemen perubahan organisasi juga sangat penting untuk menjalankan UMKM di era pandemi dan menjadikannya bisnis yang berkelanjutan. Ada beberapa hal yang perlu diperhatikan dalam melakukan perubahan baru, antara lain bagaimana bersaing di era yang selalu membuat produk baru.

\section{Referensi}

Armstrong, O. N. (2015). Finding Aid to The James R. Hansen Papers On Neil Armstrong.

Azizah, Noor, Danang Mahendra, and Budi Lofian. (2019). "Pemanfaatan E-Commerce untuk Peningkatan Strategi Promosidan Penjualan UMKM tas di Kabupaten Kudus." E-Dimas: Jurnal Pengabdian kepada Masyarakat, 10(1), 96-99.

Bekti. (2015). Mahir membuat website dengan adobe dreamweaver CS6, CSS danjquery. Yogyakarta.

Chandra, K. (2020). ANALISA PENGARUH STORE ENVIRONMENT TERHADAP REPURCHASE INTENTION DENGAN CUSTOMER EXPERIENCE SEBAGAI VARIABEL MEDIASI PADA RESTORAN GOGOGI SURABAYA. Jurnal Strategi Pemasaran, 7(1), 12.

Hadi, K., Kristiana, T., Ibie, E. N., \& Nelly, S. Panduan Penulisan Skripsi.

Hakim, Abdul. "Sektor Unggulan dan Pergeseran Sektoral Kabupaten Gresik 2011-2017 dalam Perspektif Pembangunan Ekonomi Regional." OECONOMICUS Journal of Economics 2.2 (2018): 152-174

Kertajaya dalam hijja dan Ardiansari (2015) Hijjah, Risalatin, and Anindya Ardiansari. "Pengaruh customer experience dan customer value terhadap customer loyalty melalui customer satisfaction." Management Analysis Journal 4.4 (2015).

Kotler, P., Keller, K. L., Manceau, D., \& Dubois, B. (2016). Marketing Management, 15e édition. New Jersy: Pearson Education.

Kotler, P., Kartajaya, H. and Setiawan, I. (2017). Pazarlama 4.0 gelenekselden dijitale geçiş. Optimist Yayin Grubu.

Morissan. (2015). Komunikasi pemasaran terpadu. Jakarta: Kencana.

Nadya. (2016). Peran digital marketing dalam eksistensi bisnis kuliner seblak jeletet murni. Jurnal Riset manajemen dan bisnis. 
Nasrullah dalam buku Media Sosial (2016;11), Nasrullah, Rulli. Teori dan riset media siber (cybermedia). Kencana, 2016.

POJK (Peraturan Otoritas Jasa Keuangan) No. 51 Tahun 2017 Keuangan, Otoritas Jasa. "Peraturan Otoritas Jasa Keuangan Nomor 57/POJK. 04/2017 Tentang Penerapan Tata Kelola Perusahaan Efek Yang Melakukan Kegiatan Usaha Sebagai Penjamin Emisi Efek Dan Perantara Pedagang Efek." (2017).

Pranoto, R. G. (2015). Analisa Pengaruh Customer Experience Terhadap Customer Satisfaction Pada Konsumen Di Rosetta's Cafe \& Resto Surabaya. Jurnal Strategi Pemasaran, 3(1), 1-9.

Purwiyanto, Didik, and FX Adi Purwanto. "BRAND AWARENESS SEBAGAI VARIABEL PEMEDIASI PENGARUH INTERNET MARKETING TERHADAP KEPUTUSAN PEMBELIAN. Jurnal Ilmiah Administrasi Bisnis dan Inovasi 4.2 (2021): 177-197.

Putri, Vidiyanna Rizal, and Bella Irwasyah Putra. (2017). Pengaruh Leverage, Profitability, Ukuran Perusahaan Dan Proporsi Kepemilikan Institusional Terhadap Tax Avoidance. Jurnal Manajemen Dayasaing, 19(1), 1-11.

Sanjaya dan Tarigan. (2016). Digital marketing Sanjaya, R., Tarigan, P., Siregar, L., \&Jubi, J. (2016). PENGARUH CORPORATESOCIAL RESPONSIBILITY DISCLOSURE DAN PROFITABILITAS TERHADAP NILAI PERUSAHAAN PADA PT UNILEVER INDONESIA YANG TERDAFTAR DI BURSA EFEK INDONESIA. SULTANIST: Jurnal Manajemen dan Keuangan, 4(1), 58-64.

Seputro, A. (2019). Manajemen Strategik Pemberdayaan Ekonomi UMKM Bagi Masyarakat Menengah Kebawah dalam Rangka Menangkal Paham Radikalisme dan Terorisme di Era Revolusi Industri 4.0. Jurnal Ekonomi dan Bisnis Kontemporer, 5(2).

Silalahi, E. (2020). Pengaruh Product Innovation dan Brand Image Terhadap Keputusan Pembelian Smartphone Oppo Pada Konsumen Toko Jaya Ponsel Cabang Skip Kota Bengkulu.

Sumajaya, Tikak. (2016). Rahasia Jitu Berpromosi dengan Google Adwords. Elex Media Komputindo. Thomas, P. S., Theocharous, G., Ghavamzadeh, M., Durugkar, I., \& Brunskill, E. (2017, February). Predictive off-policy policy evaluation for nonstationary decision problems, with applications to digital marketing. In Twenty-Ninth IAAI Conference.

Tjiptono. (2016). Awali, Husni. "Urgensi Pemanfaatan E-Marketing Pada Keberlangsungan Umkm Di Kota Pekalongan Di Tengah Dampak Covid-19." Balanca: Jurnal Ekonomi Dan Bisnis Islam 2, no. 1 (2020): 1-14. 